\title{
Mice Deficient in the $\alpha 7$ Neuronal Nicotinic Acetylcholine Receptor Lack $\alpha$-Bungarotoxin Binding Sites and Hippocampal Fast Nicotinic Currents
}

\author{
Avi Orr-Urtreger, ${ }^{1,4}$ Finn M. Göldner, ${ }^{2}$ Mayuko Saeki, ${ }^{2}$ Isabel Lorenzo,, ${ }^{1,4}$ Leah Goldberg, ${ }^{1,4}$ Mariella De Biasi, ${ }^{3}$ \\ John A. Dani, ${ }^{2}$ James W. Patrick, ${ }^{2}$ and Arthur L. Beaudet ${ }^{1,4}$ \\ ${ }^{1}$ Department of Molecular and Human Genetics, ${ }^{2}$ Division of Neuroscience, and ${ }^{3}$ Department of Molecular Physiology \\ and Biophysics, Baylor College of Medicine, and ${ }^{4}$ The Howard Hughes Medical Institute, Houston, Texas 77030
}

The $\alpha 7$ subunit of the neuronal nicotinic acetylcholine receptor (nAChR) is abundantly expressed in hippocampus and is implicated in modulating neurotransmitter release and in binding $\alpha$-bungarotoxin ( $\alpha$-BGT). A null mutation for the $\alpha 7$ subunit was prepared by deleting the last three exons of the gene. Mice homozygous for the null mutation lack detectable mRNA, but the mice are viable and anatomically normal. Neuropathological examination of the brain revealed normal structure and cell layering, including normal cortical barrel fields; histochemical assessment of the hippocampus was also normal. Autoradiography with $\left[{ }^{3} \mathrm{H}\right]$ nicotine revealed no detectable abnormalities of high-affinity nicotine binding sites, but there was an absence of high-affinity $\left.{ }^{125} \mathrm{I}\right] \alpha$-BGT sites. Null mice also lack rapidly desensitizing, methyllycaconitine-sensitive, nicotinic currents that are present in hippocampal neurons. The results of this study indicate that the $\alpha$-BGT binding sites are equivalent to the $\alpha 7$-containing nAChRs that mediate fast, desensitizing nicotinic currents in the hippocampus. These mice demonstrate that the $\alpha 7$ subunit is not essential for normal development or for apparently normal neurological function, but the mice may prove to have subtle phenotypic abnormalities and will be valuable in defining the functional role of this gene product in vivo.

Key words: acetylcholine receptor; $\alpha$-bungarotoxin; gene targeting; hippocampus; mouse; nicotine; $\alpha 7$ subunit
Nicotinic acetylcholine receptors (nAChRs) are members of a superfamily of ligand-gated ion channels that include muscle and neuronal nAChRs and receptors for $\mathrm{GABA}_{\mathrm{A}}$, glycine, and serotonin. Eleven genes have been identified that encode neuronal nAChR subunits: eight $\alpha$ subunits $(\alpha 2-\alpha 9)$ and three $\beta$ subunits $(\beta 2-\beta 4)$ (Sargent, 1993; McGehee and Role, 1995). Transcripts for $\alpha 8$ have been found in avians but not in mammals (Schoepfer et al., 1990), and $\alpha 9$-containing $\mathrm{nAChRs}$ are expressed in auditory hair cells (Elgoyhen et al., 1994). In the vertebrate brain, two categories of nicotinic receptors are distinguishable based on high-affinity binding of the agonist nicotine or high-affinity binding of the antagonist $\alpha$-bungarotoxin ( $\alpha$-BGT). The receptors from these two categories have distinct distributions (Wonnacott, 1986; Whiting and Lindstrom, 1988).

Biochemical and electrophysiological investigations have established that both neuronal and skeletal muscle nAChRs are heteromultimers consisting of five subunits each with four membrane-spanning segments (Sargent, 1993; McGehee and Role, 1995). Expression studies in Xenopus oocytes demonstrated that functional neuronal nAChRs are comprised of two $\alpha$ subunits and three $\beta$ subunits (Cooper et al., 1991; Bertrand and Changeux, 1995). The $\alpha 7$ subunit is an exception because it apparently cannot coassemble with other subunits when expressed in Xenopus oocytes. Thus, like $\alpha 8$ and $\alpha 9, \alpha 7$ forms a

Received July 31, 1997; revised Sept. 16, 1997; accepted Sept. 18, 1997.

This work was supported by National Institutes of Health Grants NS-21229, DA-09411, DA-04077, and TW-04861.

Correspondence should be addressed to Dr. Arthur L. Beaudet, Department of Molecular and Human Genetics, Baylor College of Medicine, One Baylor Plaza, Room T619, Houston, TX 77030.

Dr. Orr-Urtreger's present address: Tel-Aviv Sourasky Medical Center, Tel-Aviv, Israel.

Copyright (C) 1997 Society for Neuroscience $\quad 0270-6474 / 97 / 179165-07 \$ 05.00 / 0$ homo-oligomer receptor/channel that is inhibited with high affinity by $\alpha$-BGT (Couturier et al., 1990; Séguéla et al., 1993). Because $\alpha 7$ is the only subunit of these three that is widely expressed in mammalian brain, it has been suspected that $\alpha 7$ contributes to the high-affinity $\alpha$-BGT binding site, the structure and functional significance of which have been a long-standing source of controversy (Sargent, 1993).

Initially, it was thought that the $\alpha$-BGT sites did not form functional ion channels, but more recent studies have demonstrated high-affinity inhibition by $\alpha$-BGT and methyllycaconitine (MLA) of a rapidly desensitizing nicotinic current in hippocampal neurons (Albuquerque and Alkondon, 1991; Zorumski et al., 1992; Alkondon and Albuquerque, 1993; Gray et al., 1996) and in neurons of the peripheral nervous system (Zhang et al., 1994). Previous studies based on protein purification indicated that $\alpha$-BGT sites were hetero-oligomers, but the copurified components may not have been integral subunits (Sargent, 1993). In chick brain and retina, $\alpha$-BGT sites were found to be heterogeneous, containing $\alpha 7, \alpha 8$, or both, possibly in combination with another unknown component (Schoepfer et al., 1990; Gotti et al., 1995).

Despite morphological, biochemical, and electrophysiological analysis, the functions of neuronal $\alpha$-BGT binding sites and nAChRs in the mammalian brain remain largely unknown. Various neuronal nAChRs are involved in nicotine addiction (Dani and Heinemann, 1996), and there is evidence that nicotine can improve attention, rapid information processing, and working memory (Levin, 1992; Ohno et al., 1993; Picciotto et al., 1995; McGehee and Role, 1996). Cholinergic mechanisms may be involved in neurobehavioral disorders including seizures and schizophrenia (Steinlein et al., 1995; Freedman et al., 1997). A locus for juvenile myoclonic epilepsy is mapped near the $\alpha 7$ gene 
in humans (Elmslie et al., 1997). Some functions attributed to the $\alpha$-BGT sites and/or the $\alpha 7$ subunit include synapse formation (Fuchs, 1989; Pugh and Berg, 1994; Broide et al., 1995), mediation of nicotine-induced seizures (Miner and Collins, 1989; Stitzel et al., 1997), and presynaptic modulation of neurotransmitter release (McGehee et al., 1995; Gray et al., 1996; Zhang et al., 1996).

We prepared mice with a homozygous null mutation for the $\alpha 7$ subunit and found that the mice were viable and had no gross abnormalities in brain morphology, but the high-affinity $\alpha$-BGT binding sites were not present. Furthermore, $\alpha 7$-deficient hippocampal neurons lack fast, rapidly desensitizing nicotinic currents, indicating that those currents in the hippocampus are derived from $\alpha 7$-containing nAChRs that are also likely to be the major high-affinity $\alpha$-BGT binding sites in mouse brain.

\section{MATERIALS AND METHODS}

Acr $\alpha 7$ gene targeting in embryonic stem cells. A rat cDNA clone for the $\alpha 7$ subunit (Séguéla et al., 1993) was used to screen a mouse genomic DNA library prepared from the 129/SvJ strain (cat. \#946305, Stratagene, La Jolla, CA). Detailed restriction maps were prepared for genomic clones, and the intron/exon boundaries of exons 5-10 and the 3'untranslated region in exon 10 were sequenced (Fig. 1a); sequences agreed with that published for the mouse $\alpha 7$ cDNA (Orr-Urtreger et al., 1995). Sequencing was performed using an Applied Biosystems (ABI) model 373-automated DNA sequencer and dye terminator protocols as provided by the manufacturer (ABI, Foster City, CA).

The deletion mutation was introduced into the ABI 2.1 embryonic stem (ES) cell line (Soriano et al., 1991) and transmitted to the germline as described previously (Bullard et al., 1996). Chimeric mice were bred with $\mathrm{C} 57 \mathrm{BL} / 6 \mathrm{~J}$ mice, and the mice used in these studies were maintained on a mixed $129 / \mathrm{SvEv}$ and C57BL/6J background. The mutation is being back-crossed on the C57BL/6J background for future work.

Southern, Northern, and Western analyses. Southern blot hybridization was performed according to standard methods (Sambrook et al., 1989) using a hybridization solution of $0.125 \mathrm{M} \mathrm{NaPO}_{4}, \mathrm{pH} 7.0,0.25 \mathrm{M} \mathrm{NaCl}, 1$ mM EDTA, 10\% polyethylene glycol (PEG-8000), $7 \%$ SDS, and $1 \%$ bovine serum albumin (BSA) at $65^{\circ} \mathrm{C}$ overnight followed by washing to a final stringency of $0.2 \times \mathrm{SSC} / 0.1 \% \mathrm{SDS}$ at $65^{\circ} \mathrm{C}$ and autoradiography at $-80^{\circ} \mathrm{C}$.

Total RNA was isolated from brain after homogenization in Ultraspec II (Tel Test, Houston, TX). Total RNA was resolved on a $1.2 \%$ agarose gel in $10 \mathrm{~mm} \mathrm{NaPO}$ buffer, pH 6.8, after glyoxal/dimethylsulfoxide denaturation according to standard methods (Sambrook et al., 1989). RNA was visualized by ethidium bromide staining, transferred to Hybond $\mathrm{N}^{+}$membrane, and hybridized with full-length (mouse) Acr $\alpha 7$ cDNA as probe. Hybridization and washing conditions were identical to those used for Southern hybridization.

For immunoblotting, whole brain from three homozygous $\alpha 7$ null $(-/-)$ mice and three littermate control $(+/+)$ mice was homogenized in $10 \mathrm{ml}$ of ice-cold buffer containing $10 \mathrm{~mm}$ HEPES, pH 7.4, $5 \mathrm{~mm}$ EDTA, $5 \mathrm{~mm}$ EGTA, and $1 \mathrm{~mm}$ phenylmethylsulfonylfluoride (PMSF). Total membranes were pelleted by centrifugation at $100,000 \times g$ for $60 \mathrm{~min}$ at $4^{\circ} \mathrm{C}$. Membranes were resuspended in $10 \mathrm{ml}$ of solubilization buffer containing $10 \mathrm{~mm}$ HEPES, pH 7.4, 5 mM EDTA, 5 mM EGTA, $1 \%$ Triton X-100, and $1 \mathrm{~mm}$ PMSF and shaken for $2 \mathrm{hr}$ at $4^{\circ} \mathrm{C}$. The detergentsolubilized membrane protein supernatant was recovered after centrifugation at $100,000 \times g$ for $60 \mathrm{~min}$. Protein concentration was determined by the BCA method (Pierce, Rockford, IL). Solubilized membrane proteins $(36 \mathrm{mg})$ were incubated overnight with $25 \mu \mathrm{l}$ of $\alpha$-cobratoxin matrix (0.5 mg toxin/ml matrix, Sigma, St. Louis, MO), which was preequilibrated with the solubilization buffer. The matrix was recovered by brief centrifugation in a benchtop microcentrifuge and washed four times with $1 \mathrm{ml}$ of solubilization buffer. Bound receptors were eluted with $30 \mu \mathrm{l}$ of SDS/sample buffer and separated by SDS-PAGE followed by transfer to a nitrocellulose membrane. The membrane was blocked for 30 min with 5\% dry milk and $0.1 \%$ Tween 20 in PBS. A polyclonal sheep antibody (Chen and Patrick, 1997) against a bacterial expressed extracellular domain of the rat $\alpha 7$ protein was diluted $1: 1000$ in the above blocking solution and incubated with the membrane overnight at $4^{\circ} \mathrm{C}$. The membrane was washed and probed with a rabbit anti-sheep IgG antibody coupled to peroxidase (Cappel, Durham, NC) at a dilution of 1:10,000. After we washed the membranes, we detected peroxidase ac- tivity using enhanced chemiluminescence (ECL; Amersham, Arlington Heights, IL).

Nicotine and $\alpha-B G T$ autoradiography. For nicotine autoradiography, coronal sections $(10 \mu \mathrm{m})$ of fresh frozen mouse brain were prepared and dried onto slides. $\left[{ }^{3} \mathrm{H}\right]$ nicotine $(75 \mathrm{Ci} / \mathrm{mmol}$, DuPont NEN, Boston,

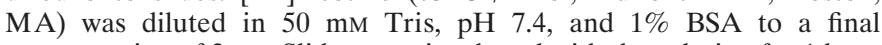
concentration of $2 \mathrm{nM}$. Slides were incubated with the solution for $1 \mathrm{hr}$ at room temperature. Nonspecific binding was assessed by incubating sections with an excess $(10 \mu \mathrm{M})$ of unlabeled ligand nicotine. Slides were washed twice in ice-cold $50 \mathrm{~mm}$ Tris, $\mathrm{pH} \mathrm{7.4,} \mathrm{for} 2$ min each, dried, and exposed to tritium-sensitive film (3H Hyperfilm, Amersham, Arlington Heights, IL) for 12 weeks.

For $\alpha$-BGT autoradiography, unfixed, frozen brain was sectioned at 20 $\mu \mathrm{m}$, thaw-mounted onto slides, and dried. Sections were preincubated for $30 \mathrm{~min}$ at room temperature in $1 \% \mathrm{BSA}$ and $50 \mathrm{~mm}$ Tris, $\mathrm{pH}$ 7.4, either with or without $10 \mu \mathrm{M}$ unlabeled $\alpha$-BGT as a competitor. [ $\left.{ }^{125} \mathrm{I}\right] \alpha$-BGT (initial specific activity of $4.8 \times 10^{8} \mathrm{cpm} / \mathrm{nmol}$ and used within 1 half-life; Amersham) was diluted in the above blocking solution to a final concentration of $5 \mathrm{~nm}$ and added to the sections for $1 \mathrm{hr}$ at room temperature. Sections were washed four times for $5 \mathrm{~min}$ in ice-cold $50 \mathrm{~mm}$ Tris, $\mathrm{pH}$ 7.4, after which they were dried and exposed to Kodak BioMax MR film for 1-3 d.

Histological analysis. Brain tissue for Nissl stain, immunohistochemistry, and acetylcholinesterase histochemistry was prepared by perfusion with $\mathrm{PBS} / 4 \%$ paraformaldehyde in $\mathrm{PBS}, \mathrm{pH}$ 7.4, and post-fixed overnight at $4^{\circ} \mathrm{C}$ in the same fixative. Tissue was equilibrated in $30 \%$ sucrose, frozen in prechilled isopentane, and sectioned at $30-50 \mu \mathrm{m}$.

For Nissl stains, cleared and rehydrated sections were incubated with $0.5 \%$ cresyl violet acetate, washed, rapidly dehydrated, cleared, and mounted on coverslips. Immunohistochemistry for glial fibrillary acidic protein (GFAP) was performed with antibody against GFAP (clone G-A-C, mouse IgG1, Boehringer Mannheim, Indianapolis, IN); freefloating sections were stained according to a standard ABC-protocol (Vector Laboratories, Burlingame, CA). Staining for acetylcholine esterase was performed according to a published protocol (Geneser-Jensen and Blackstad, 1971). A modified Timm stain protocol was used to demonstrate mossy fibers in paraffin-embedded, $8-\mu \mathrm{m}$-thick sections of the hippocampus (Sloviter, 1982).

Labeling for cytochrome oxidase was performed on mounted sections using PBS containing $4 \%$ sucrose, $25 \mu \mathrm{M}$ cytochrome $c$ (type III, Sigma), and $1 \mathrm{~mm}$ diaminobenzidine tetrahydrochloride at $37^{\circ} \mathrm{C}$ until staining of the desired intensity could be detected, after which the reaction was stopped by washing in PBS.

Electrophysiology. Hippocampal neurons were obtained from newborn mice (12-36 hr postnatal). The brain was removed immediately and kept throughout the dissection in a cold solution containing (in $\mathrm{mM}$ ): 137 $\mathrm{NaCl}, 5.3 \mathrm{KCl}, 0.2 \mathrm{Na}_{2} \mathrm{HPO}_{4}, 0.2 \mathrm{KH}_{2} \mathrm{PO}_{4}$, and $10 \mathrm{HEPES}, \mathrm{pH}$ 7.4. Hippocampal tissue from both hemispheres was gently removed and cut into small pieces. The tissue was digested for $40 \mathrm{~min}$ at $37^{\circ} \mathrm{C}$ in a dissecting solution containing $20 \mathrm{U} / \mathrm{ml}$ papain (Worthington, Freehold, $\mathrm{NJ})$. After digestion, the tissue was triturated with fire-polished Pasteur pipettes of decreasing diameter. Hippocampal cells were plated on collagen/poly-D-lysine-coated coverslips (Fisher, Pittsburgh, PA). A separate cell culture was prepared for each mouse in litters born to heterozygote parents, with the expectation that $+/+,+/-$, and $-/-$ pups would occur in a ratio of 1:2:1. The genotype of each mouse was determined after electrophysiological studies were completed and interpreted. Cells were kept in minimum essential medium (MEM) containing 5\% fetal bovine serum (HyClone, Logan, UT), $1 \mu \mathrm{l} / \mathrm{ml}$ Serum Extender (Collaborative Research, Bedford, MA), $0.5 \mu \mathrm{M}$ tetrodotoxin (Calbiochem, Pasadena, CA), $20 \mathrm{~mm}$ glucose, and $2.5 \mathrm{~mm} \mathrm{MgCl}_{2}$. Hippocampal neurons were studied from day 15 to day 25 in culture because nicotinic currents are larger and more commonly expressed after day 10 in culture (Alkondon and Albuquerque, 1993; Gray et al., 1996).

Whole-cell currents were elicited with $500 \mu \mathrm{M}$ nicotine and measured with standard patch-clamp techniques (Zarei and Dani, 1995). The external bath solution contained (in mM): $150 \mathrm{NaCl}, 2.5 \mathrm{KCl}, 5 \mathrm{CaCl}_{2}$, $1 \mathrm{MgCl}_{2}, 10$ glucose, 10 HEPES, $\mathrm{pH} 7.4,0.5 \mu \mathrm{M}$ tetrodotoxin, and $10 \mu \mathrm{M}$ 6-cyano-7-nitroquinoxaline-2,3-dione (CNQX). The pipette solution contained (in mM): $150 \mathrm{CsCH}_{3} \mathrm{SO}_{3}, 5 \mathrm{NaCl}, 0.2$ EGTA, $2 \mathrm{Na}_{2} \mathrm{ATP}, 2$ MgATP, $0.3 \mathrm{Na}_{3} \mathrm{GTP}$, and $10 \mathrm{HEPES}, \mathrm{pH}$ 7.3. The holding potential was $-60 \mathrm{mV}$. Currents were amplified and filtered on line $(1 \mathrm{kHz})$ using an Axopatch 1D voltage clamp with a 4-pole Bessel filter and were digitally sampled to exceed the Nyquist criterion. No series resistance compensation or leak subtraction was performed. Drugs were applied through flow pipes mounted on a motorized manipulator (Newport, Fountain 


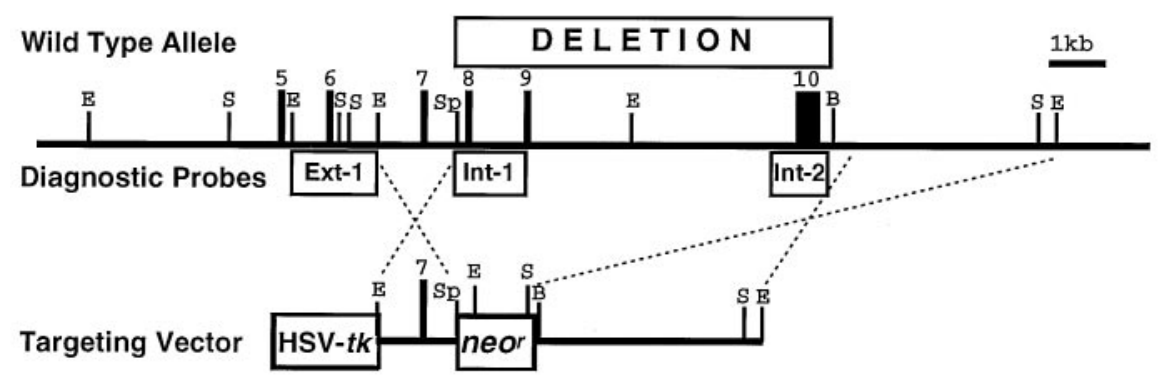

\section{Targeted Allele}

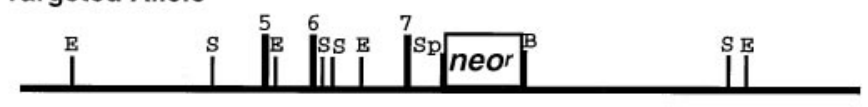

\section{Wild Type \\ Mutant}

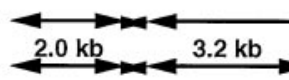

b
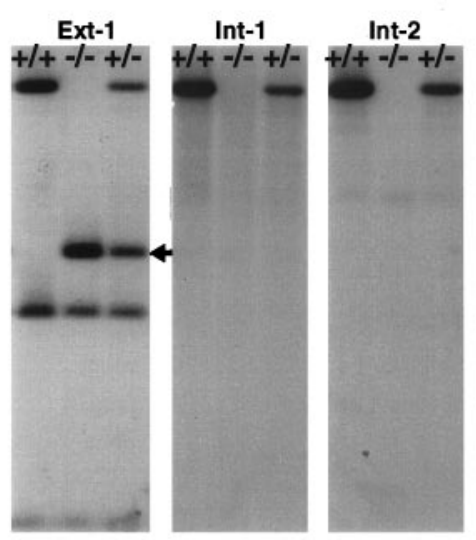

C

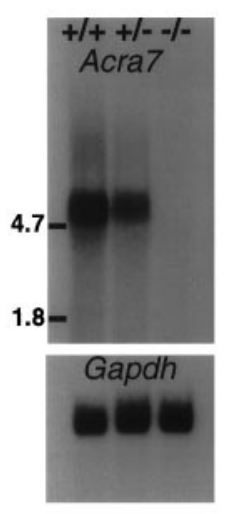

\section{d}

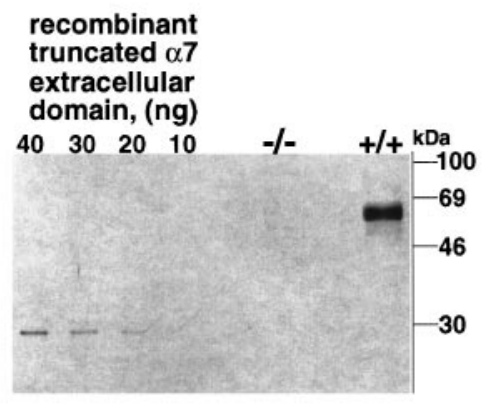

Valley, CA) and connected to computer-driven valves (General Valve Corporation, Fairfield, NJ). Nicotine and MLA were applied for $600 \mathrm{msec}$ and $90 \mathrm{sec}$, respectively. Solution changes were complete in $\sim 30 \mathrm{msec}$ (Gray et al., 1996). All experiments were conducted at room temperature.

\section{RESULTS}

\section{Preparation of a null mutation for the $\alpha 7$ subunit}

Mice deficient in the $\alpha 7$ subunit were generated by introducing a $7 \mathrm{~kb}$ deletion into ES cells followed by transmission to the germline. The mutation deletes the last three exons $(8-10)$ of the $\alpha 7$ locus (Acr $\alpha 7)$; these exons encode the second transmembrane domain (MII), forming the putative ion channel and the third and fourth transmembrane domains and the cytoplasmic loop (Fig.

Figure 1. Gene targeting of the neuronal nAChR $\alpha 7$ subunit. $a$, Partial genomic structure of the murine $\alpha 7$ subunit gene including exons $5-10$ is shown. The homologous recombination event generated a $7 \mathrm{~kb}$ genomic deletion that removes exons 8-10. Restriction enzyme sites are as follows: $E, E c o$ RI; $S, S a c$; Sp, SpeI; B, Bam HI. The diagnostic probes include a flanking probe to genotype ES cells and animals (external probe 1, Ext-1) and two internal probes (Int-1 and Int-2) to confirm the deletion. The targeting vector was used to obtain a replacement mutation and contains a neomycin resistance gene $\left(\right.$ nеo $\left.{ }^{r}\right)$ as a positive selectable marker and the herpes simplex thymidine kinase gene (HSV-tk) as a negative selectable marker. The sites of predicted homologous recombination are shown. The expected wild-type and mutant restriction fragments, after $\mathrm{SacI}$ enzyme digest and hybridization with Ext-1 probe, are shown below the targeting vector. $b$, Southern blot analysis identifies the $\alpha 7$ homozygous null $(-/-)$, heterozygous $(+/-)$, and littermate control $(+/+)$ animals using each of the three probes as indicated. The small arrow indicates the mutant band with the Ext-1 probe. Constant fragments of 2.0 and $0.3 \mathrm{~kb}$ are seen with the Ext-1 probe. $c$, Northern blot analysis of $\alpha 7$ gene expression in brains of $(+/+),(+/-)$, and $(-/-)$ animals, using the Acr 7 cDNA (Acra 7$)$ and control (Gapdh) probes. $d$, Western blot analysis of brains from $+/+$ and $-/-$ animals. As a positive control, 10, 20, 30, and $40 \mathrm{ng}$ of recombinant extracellular domain of the rat $\alpha 7$ protein (Chen and Patrick, 1997) were used.
$1 a)$. Southern blot analysis using a flanking genomic probe detected a new $3.2 \mathrm{~kb}$ mutant fragment in the heterozygote $(+/-)$ and homozygote $(-/-)$ mice (Fig. $1 b)$; adjacent smaller DNA fragments were unchanged. Analysis with genomic probes from the regions of the deleted exons confirmed the absence of these exons (Fig. 1b). The effect of the mutation on mRNA transcripts was examined using Northern blotting, and no detectable transcripts were found in homozygous mutant mice, indicating that any altered transcripts were unstable (Fig. 1c). Because the deletion leaves intact the coding sequences for the extracellular, ligand-binding, and toxin-binding domains of the $\alpha 7$ subunit, a partially functional, truncated protein could occur; this possibility 
a
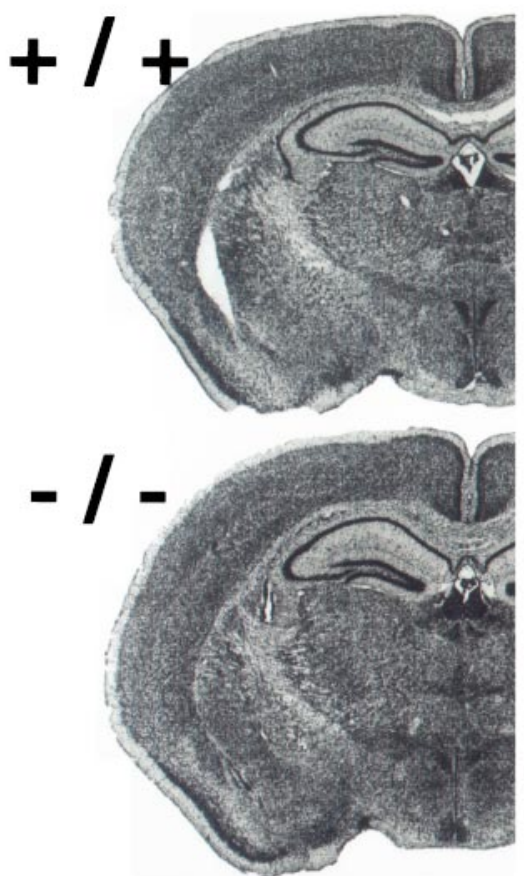

C

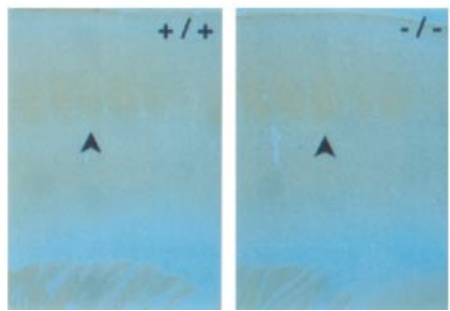

b
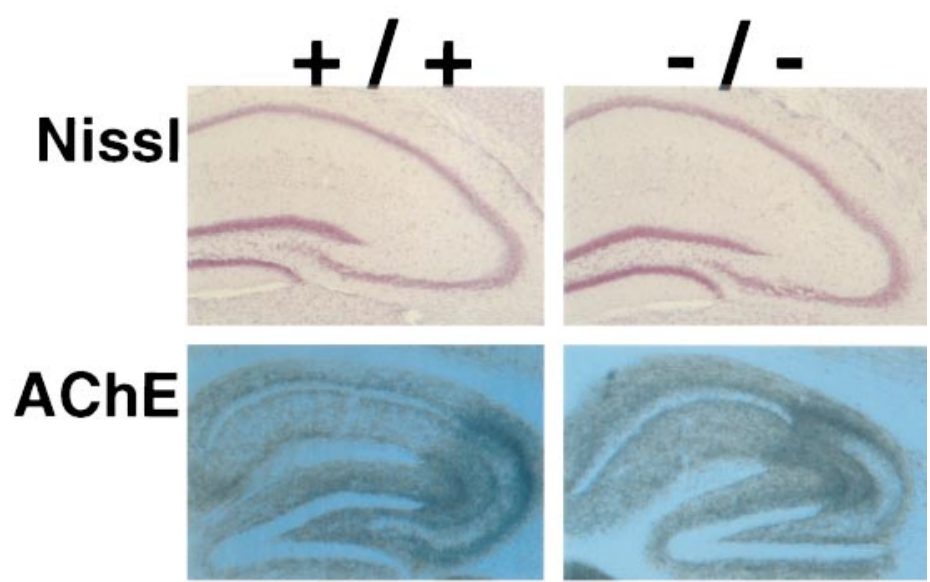

GFAP
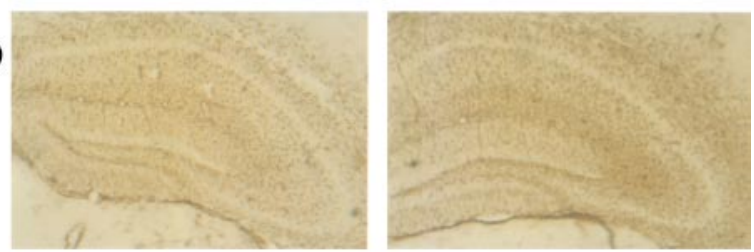

\section{Timm}
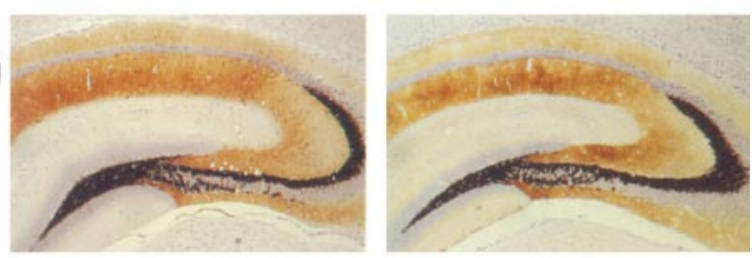

Figure 2. Neuroanatomy and histochemistry of mutant mice. Panels with $+/+$ and $-/-$ indicated are as follows: $(a)$ coronal sections of brain with Nissl stain; (b) sagittal sections of hippocampus with Nissl stain (Nissl), AChE-acetylcholinesterase (AChE), glial fibrillary acidic protein (GFAP), and Timm stain (Timm) as indicated; and (c) sections through the barrels (arrows) in the primary somatosensory cortex stained with cytochrome oxidase.

is unlikely, however, considering the results of Northern blotting. Immunoblots (Fig. $1 d$ ) of protein extracts prepared by $\alpha$-BGT affinity chromatography from wild-type and mutant mice were probed with antibodies to the N-terminal portion of the $\alpha 7$ subunit, demonstrating absence of toxin-binding $\alpha 7$ protein in homozygous mice. The results of Northern analysis and immunoblotting confirm the generation of a null mutation for the $\alpha 7$ subunit.

\section{Normal growth, viability, and neuroanatomy in $\alpha 7$ null mice}

The $\alpha 7$ null mice are viable, are present in the expected proportion in matings of heterozygote mice, grow to normal size, and show no obvious physical or neurological deficit. Homozygous male and female mice are fertile, although there may be some reduction in fertility.

The overall brain structure and organization in homozygous null mice appear normal as assessed by comparable Nissl-stained sections in $+/+$ and $-/-$ mice (Fig. $2 a$ ). All major neuronal structures are intact, and there are no apparent abnormalities in cell density or layering of cortical structures. Because $\alpha 7$ is expressed most abundantly in the hippocampus, a more detailed anatomical analysis was performed (Fig. 2b). Nissl staining revealed that the major classes of neurons (i.e., granule cells, pyramidal cells, and hilar interneurons) are present in their appropriate location and, therefore, do not appear to depend on the presence of $\alpha 7$ for their formation or migration within the network. Histochemical staining for acetylcholinesterase (AChE) was performed to evaluate the hippocampus, and no abnormalities were found. Because a mutation in an $\alpha 7$-like gene in $C$. elegans is associated with neurodegeneration (Treinin and Chalfie, 1995), we performed immunohistochemical staining for GFAP, a marker for astrocytes, to search for glial scars representing neuronal injury or cell death. No glial scars were found in the hippocampus of mutant mice, suggesting that deficiency of $\alpha 7$ does not lead to abnormal neuronal degeneration in this region. The status of intrahippocampal connections, particularly the mossy fiber projections, was evaluated by Timm staining, and no differences were found between mutants and controls.

The primary somatosensory cortex of rodents is characterized by anatomically defined barrel structures that reflect projections from the whiskers. Because staining with $\alpha$-BGT outlines barrels at the time of their appearance, it was suggested that $\alpha 7$ may be important for barrel formation (Fuchs, 1989; Broide et al., 1995). Mutant animals were analyzed for the presence of barrels using histochemical staining for cytochrome oxidase (Fig. $2 c$ ). Sections through the somatosensory cortex of mutant animals show characteristic barrel-like structures that were indistinguishable from those in wild-type littermates, indicating that structures with the general appearance of barrels develop in the absence of $\alpha 7$. 


\section{$+1+$

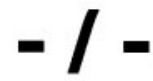 \\ $125 \mathrm{I}-\alpha-\mathrm{BTX}$}

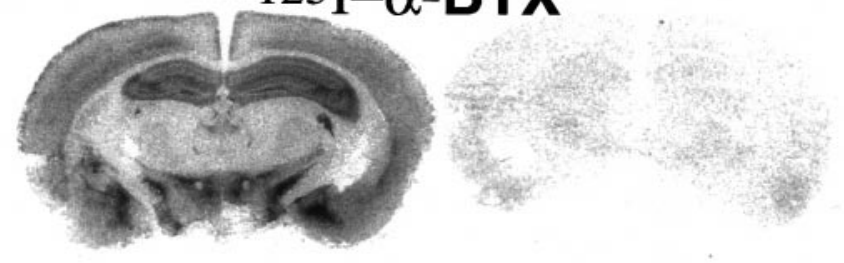

cold $\alpha-B T X$
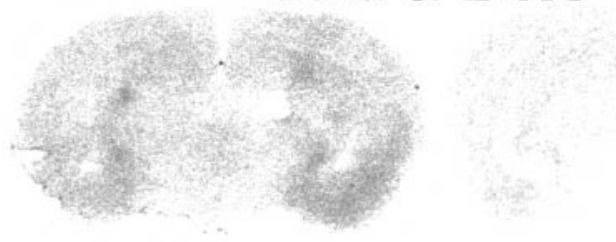

3H-Nicotine

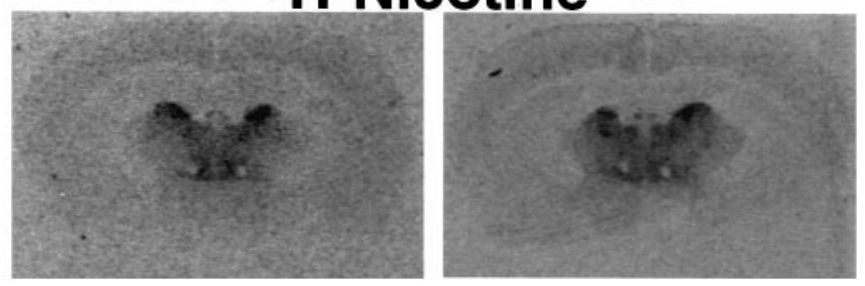

Figure 3. Nicotine and $\alpha$-BGT binding in mutant mice. Autoradiography was performed with $\left[{ }^{3} \mathrm{H}\right]$ nicotine and $\left[{ }^{125} \mathrm{I}\right] \alpha$-BGT as described in Materials and Methods with $+/+$ mice shown on the left and $-/-$ shown on the right. The panels marked cold $\alpha-B G T$ included excess nonradioactive $\alpha$-BGT as competitor.

\section{Null mice lack $\alpha$-BGT binding sites}

The distribution of high-affinity nicotine binding sites and $\alpha$-BGT binding sites in the brain of mutant $(-/-)$ and control $(+/+)$ littermates was examined (Fig. 3). The pattern of distribution of binding sites for these two ligands is significantly different, with the greatest abundance of high-affinity nicotine binding sites in thalamic structures and the predominance of $\alpha$-BGT binding sites in the hippocampus (Clarke et al., 1985). The use of $\left[{ }^{3} \mathrm{H}\right]$ nicotine at low nanomolar concentrations detects only high-affinity binding sites and does not detect low-affinity nicotine binding sites such as those present in hippocampus (Clarke et al., 1985; Picciotto et al., 1995). The pattern of high-affinity nicotine binding sites in mutant and control animals was indistinguishable, and there was no evidence for significant upregulation of nicotine binding sites in $\alpha 7$-deficient mice (Fig. 3). The distribution of $\alpha$-BGT binding sites in the $\alpha 7$-deficient mice is of particular interest because of the possibility that $\alpha 7$ represents the major or sole $\alpha$-BGT binding protein in rodent brain. Brain sections of homozygous null mice and littermate controls were analyzed using autoradiography with $\left[{ }^{125} \mathrm{I}\right] \alpha$-BGT (Fig. 3). The characteristic distribution of $\alpha$-BGT binding sites was found in normal mice with a prominent pattern in telencephalic structures such as the hippocampus, amygdala, and neocortex. In contrast, there was no significant $\alpha$-BGT binding above background levels in the null mice, suggesting that $\alpha 7$ is required for high-affinity $\alpha$-BGT binding sites in the mouse brain.

\section{Null mice lack hippocampal fast nicotinic currents}

Electrophysiological evaluation of the mice was important, because rapidly desensitizing nicotinic currents in hippocampal neurons are attributed to expression of $\alpha 7$ (Alkondon and Albuquerque, 1993; Gray et al., 1996). Neonatal littermates from matings of heterozygotes were examined, and genotypes were determined after collection and interpretation of the electrophysiological data. Hippocampal neurons were cultured from neonatal mice, and rapid application of $500 \mu \mathrm{M}$ nicotine evoked a fast, desensitizing current that could be blocked by $5 \mathrm{~nm}$ MLA, a potent and selective antagonist of $\alpha 7$-containing nAChRs (Alkondon and Albuquerque, 1993; Gray et al., 1996) (Fig. 4a). The block by MLA was reversible after 2 min of washout with bath solution. When neurons from $\alpha 7$-deficient mice were exposed to $500 \mu \mathrm{M}$ nicotine, no currents could be recorded; none of the 35 cells from the four null mice examined revealed any current (Fig. 4c). Neurons from both wild-type and heterozygous mice showed bimodal response distributions to nicotine; some cells responded by giving measurable currents, and other cells had no response. The lack of nicotine-induced currents in the $\alpha 7$ null mice indicates that the predominant currents found in cultured hippocampal neurons from control mice are dependent on expression of the $\alpha 7 \mathrm{nAChR}$.

\section{DISCUSSION}

A mutation deleting numerous exons was introduced into the gene for the $\alpha 7$ subunit, completely eliminating its potential for participation in an ion channel. Although this mutation might allow for the synthesis of a truncated protein with ligand-binding capacity, Northern blotting and immunoblotting studies demonstrate the absence of detectable mRNA or protein and ensure that this mutation produces a null allele. The function of the $\alpha 7$ subunit is largely unknown, although many possible roles have been discussed (Sargent, 1993; McGehee and Role, 1995). Homozygous mutant mice demonstrate normal general appearance, growth, survival, gait, and anatomy. Histological evaluation of the nervous system did not reveal any developmental abnormalities. Thus, the phenotypic consequences of deficiency of the $\alpha 7$ nAChR are not immediately obvious.

There is evidence that expression of the $\alpha 7$ subunit may be correlated with differences in nicotine binding, nicotine-induced seizures, nicotine preference, and effect of nicotine on body temperature in various strains of mice (Miner and Collins, 1989; Stitzel et al., 1997), and it will be of interest to analyze the mutant mice for these traits. In addition, $\alpha 7$-deficient mice might be expected to show resistance to $\alpha$-conotoxin (Johnson et al., 1995). There is also a report suggesting that differences in response to auditory stimuli that are associated with schizophrenia show linkage to human chromosome 15 in a region near the $\alpha 7$ locus (Freedman et al., 1997). There is evidence of increased smoking in schizophrenics, and $\alpha 7$ has been proposed as having a role in the pathophysiology of schizophrenia (Freedman et al., 1994, 1997). It will be important to evaluate learning and behavior in the mutant mice, and the mutation is being back-crossed to $\mathrm{C} 57 \mathrm{BL} / 6 \mathrm{~J}$ background, because nicotine-induced seizures, auditory gaiting, and learning are all known to be variable among inbred strains of mice (Miner and Collins, 1989; Stitzel et al., 1997). Behavioral studies seeking to identify schizophrenia-like behavior in mice (Dains et al., 1996; Kafka and Corbett, 1996) will also be of interest.

The hippocampus is a center for learning and memory and receives cholinergic innervation mainly from the medial septum and diagonal band (Woolf, 1991). Presynaptic terminals contain- 
A

Figure 4. Nicotine induces currents in control but not in $\alpha 7$ null mice. $a$, Nicotine $(0.5 \mathrm{~mm})$ evoked a fast, desensitizing current in hippocampal neurons from control $(+/+)$ mice. The currents were completely blocked by 5 nM MLA ( $90 \mathrm{sec}$ application) and recovered to $89 \%$ of the original peak current after washout (recovery at $150 \mathrm{sec}$ ). The solid black lines indicate the duration of the nicotine applications. $b$, Nicotine $(0.5 \mathrm{~mm})$ failed to induce ionic currents in all of the hippocampal cells studied from $\alpha 7$ null mice. $c$, The majority (72\%) of hippocampal cells from wild-type $(+/+)$ mice ( 3 animals) showed currents in response to nicotine application, and $28 \%$ did not show any response. Approximately half $(54 \%)$ of hippocampal cells from $\alpha 7$ heterozygous $(+/-)$ mice (8 animals) responded to nicotine, whereas $46 \%$ did not show any current. No nicotine-induced current could be recorded in any of the cells from $\alpha 7$ null $(-/-)$ mice (4 animals, 35 cells). $n$, Number of cells recorded; $I$, current in pA.

C
$(+/+)$
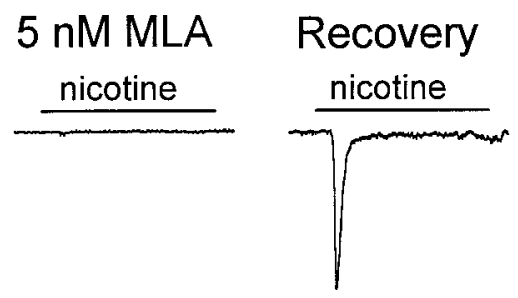

Control
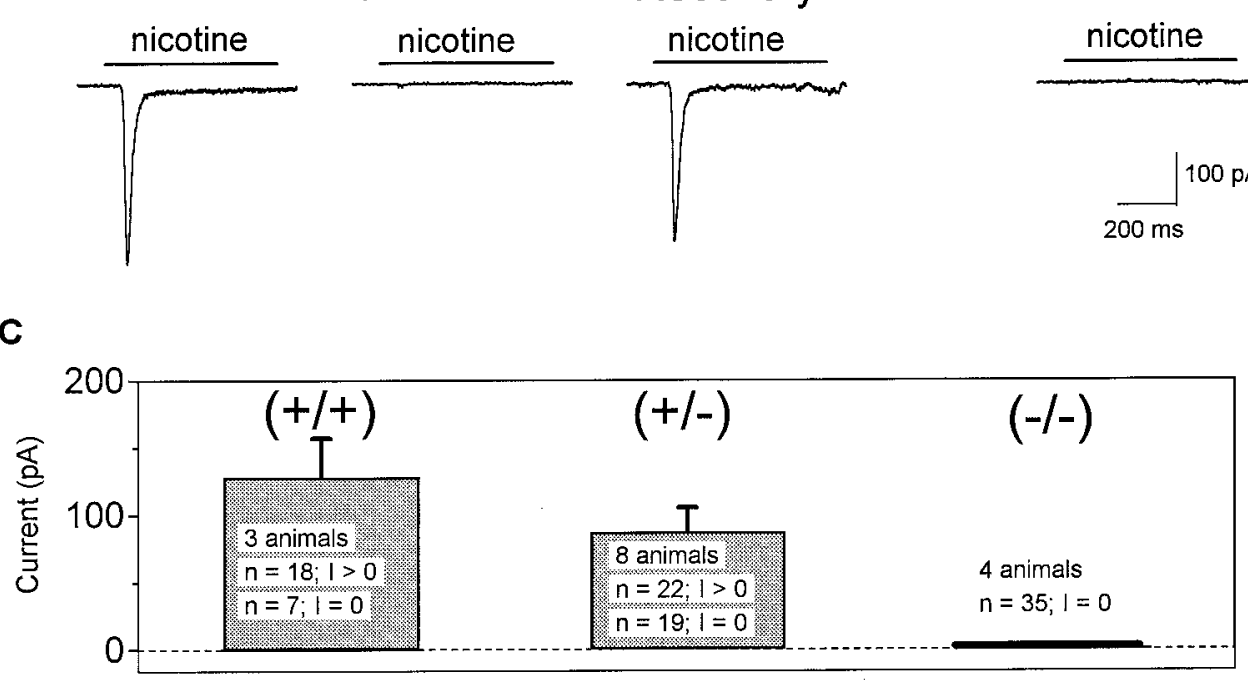

ing choline acetyltranferase (the enzyme that catalyzes the synthesis of acetylcholine) have been found to synapse directly onto pyramidal and granule cells and their dendrites (Alonso and Amaral, 1995). Nicotine and cytisine autoradiography and in situ hybridization using probes for various subunits indicate that nAChRs are expressed throughout the hippocampus and that $\alpha 7$ and $\beta 2$ are the most abundant subunits (Deneris et al., 1988; Wada et al., 1990; Dineley-Miller and Patrick, 1992; Perry et al., 1993; Séguéla et al., 1993). The hippocampus also is known to possess a high density of $\alpha$-BGT binding sites. Our results with $\alpha 7$ null mice indicate that the $\alpha$-BGT sites are not detected when the $\alpha 7$ gene is disrupted, but the high-affinity nicotine sites in the brain are not detectably different. Although the results do not eliminate the possibility of other low-affinity sites or of another very minor component of $\alpha$-BGT sites, the major $\alpha$-BGT sites that have been at the center of attention and controversy are absent in $\alpha 7$ null mice. These results indicate that, unlike chick, in which multiple forms of $\alpha$-BGT sites are seen based on the presence of either the $\alpha 7$ or the $\alpha 8$ subunit (Schoepfer et al., 1990; Gotti et al., 1995), the $\alpha$-BGT sites require the $\alpha 7$ subunit in mice.

In rat hippocampal slices and cultures, it was found that nicotinic agonists can enhance glutamate release by acting through presynaptic nAChRs (Gray et al., 1996). This enhanced release of glutamate and the rapidly desensitizing nicotinic currents were inhibited by $\alpha$-BGT and MLA, indicating that those nAChRs contain the $\alpha 7$ subunit. Although other types of nicotinic currents occasionally could be seen, the predominant current displayed fast activation and rapid desensitization (Alkondon and Albuquerque, 1993; Gray et al., 1996). Similarly for mice, we found nicotine-activated currents in the majority (72\%) of hippocampal neurons, and in all cases those currents were rapid and inhibited by MLA. In cultures from four $\alpha 7$ null mice, however, none of the 35 hippocampal neurons that were studied displayed nicotinic currents. These results suggest that the rapid nicotinic currents in hippocampal neurons are mediated by the $\alpha$-BGT binding sites and that those sites require the $\alpha 7$ subunit for their formation into a receptor/ion channel complex.

Whether homo-oligomer $\alpha 7$ receptors exist in the brain is still open to question, but evidence is mounting that $\alpha 7$ might form a receptor without requiring any of the other presently known nicotinic subunits. The $\alpha 7$ null mice lack the $\alpha$-BGT sites but have the high-affinity nicotine sites, and $\beta 2$ null mice lack the nicotine sites but still have the $\alpha$-BGT sites (Picciotto et al., 1995). These results indicate that $\beta 2$ is not required for the $\alpha$-BGT site and that $\alpha 7$ is not required for the high-affinity nicotine site. Because $\alpha 7$ and $\beta 2$ are by far the predominant subunits in the hippocampus, it is unlikely that any other known subunit is abundant enough to be present in all of the $\alpha$-BGT sites in the hippocampus. Thus, it is unlikely that all of the $\alpha$-BGT sites contain a known subunit other than $\alpha 7$. In addition, $\alpha$-BGT sites from PC12 cells showed size and pharmacological similarities to homo-oligomeric chimeric $\alpha 7$ receptors expressed in tsA201 cells (Rakhilin et al., 1996), further supporting the hypothesis that homo-oligomeric $\alpha 7$ receptors may exist naturally as well as in heterologous expression systems.

Nicotine obtained from tobacco has complex psychopharmacological effects (Dani and Heinemann, 1996), but it is reasonable to hypothesize that nicotine acts, in part, on the hippocampus (Gray et al., 1996) to enhance learning and memory on various tasks (Levin, 1992; Ohno et al., 1993). The results of the present work suggest that the actions of nicotine on the hippocampus are likely to arise largely from activation, desensitization, or modification of $\alpha$-BGT binding sites that contain the $\alpha 7$ subunit.

Although it may be surprising that mice with complete deficiency of the $\alpha 7$ subunit do not have gross or obvious abnormalities, these mice do demonstrate that the $\alpha 7$ subunit is not essential for normal development or for superficially normal neurological function. These mice may prove to have subtle phenotypic abnormalities, and they will be valuable in defining the functional role of the $\alpha 7$ subunit in vivo.

\section{REFERENCES}

Albuquerque EX, Alkondon M (1991) Initial characterization of the nicotinic acetylcholine receptors in rat hippocampal neurons. J Recept Res 11:1001-1021.

Alkondon M, Albuquerque EX (1993) Diversity of nicotinic acetylcholine receptors in rat hippocampal neurons. I. Pharmacological and 
functional evidence for distinct structural subtypes. J Pharmacol Exp Ther 265:1455-1473.

Alonso JR, Amaral DG (1995) Cholinergic innervation of the primate hippocampal formation. I. Distribution of choline acetyltransferase immunoreactivity in the Macaca fascicularis and Macaca mulatta monkeys. J Comp Neurol 355:135-170.

Bertrand D, Changeux J-P (1995) Nicotinic receptor: an allosteric protein specialized for intercellular communication. Neuroscience 7:75-90.

Broide RS, O'Connor LT, Smith MA, Smith JAM, Leslie I (1995) Developmental expression of $\alpha_{7}$ neuronal nicotinic receptor messenger RNA in rat sensory cortex and thalamus. Neuroscience 67:83-94.

Bullard DC, Kunkel EJ, Kubo H, Hicks MJ, Lorenzo I, Doyle NA, Doerschuk CM, Ley K, Beaudet AL (1996) Infectious susceptibility and severe deficiency of leukocyte rolling and recruitment in E-selectin and P-selectin double mutant mice. J Exp Med 183:2329-2336.

Chen D, Patrick JW (1997) The alpha-bungarotoxin-binding nicotinic acetylcholine receptor from rat brain contains only the alpha7 subunit. J Biol Chem 272:24024-24029.

Clarke PBS, Schwartz RD, Paul SM, Pert CB, Pert A (1985) Nicotinic binding in rat brain: autoradiographic comparison of $\left[{ }^{3} \mathrm{H}\right]$ acetylcholine, $\left[{ }^{3} \mathrm{H}\right]$ nicotine, and $\left[{ }^{125} \mathrm{I}\right]-\alpha$-bungarotoxin. J Neurosci 5:1307-1315.

Cooper E, Couturier S, Ballivet M (1991) Pentameric structure and subunit stoichiometry of a neuronal nicotinic acetylcholine receptor. Nature 350:235-238.

Couturier S, Bertrand D, Matter J-M, Hernandez M-C, Bertrand S, Millar N, Valera S, Barkas T, Ballivet M (1990) A neuronal nicotinic acetylcholine receptor subunit $(\alpha 7)$ is developmentally regulated and forms a homo-oligomeric channel blocked by $\alpha$-BTX. Neuron 5:847-856.

Dains K, Hitzemann B, Hitzemann R (1996) Genetics, neuroleptic response and the organization of cholinergic neurons in the mouse striatum. J Pharmacol Exp Ther 279:1430-1438.

Dani JA, Heinemann S (1996) Molecular and cellular aspects of nicotine abuse. Neuron 16:905-908.

Dineley-Miller K, Patrick J (1992) Gene transcripts for the nicotinic acetylcholine receptor subunit, $\beta 4$, are distributed in multiple areas of the rat central nervous system. Mol Brain Res 16:339-344.

Elgoyhen AB, Johnson DS, Boulter J, Vetter DE, Heinemann S (1994) $\alpha 9$ : an acetylcholine receptor with novel pharmacological properties expressed in rat cochlear hair cells. Cell 79:705-715.

Elmslie FV, Rees M, Williamson MP, Kerr M, Kjeldsen MJ, Pang KA, Sundqvist A, Friis ML, Chadwick D, Richens A, Covanis A, Santos M, Arzimanoglou A, Panayiotopoulos CP, Curtis D, Whitehouse WP, Gardiner RM (1997) Genetic mapping of a major susceptibility locus for juvenile myoclonic epilepsy on chromosome 15q. Hum Mol Genet 6:1329-1334.

Freedman R, Adler LE, Bickford P, Byerley W, Coon H, Cullum CM, Griffith JM, Harris JG, Leonard S, Miller C, Myles-Worsley M, Nagamoto HT, Rose G, Waldo M (1994) Schizophrenia, nicotinic receptors, and cigarette smoking. Harvard Rev Psychiatry 2:179-192.

Freedman R, Coon H, Myles-Worsley M, Orr-Urtreger A, Olincy A, Davis A, Polymeropoulos M, Holik J, Hopkins J, Hoff M, Rosenthal J, Waldo MC, Reimherr F, Wender P, Yaw J, Young DA, Breese CR, Adams C, Patterson D, Adler LE, Kruglyak L, Leonard S, Byerley W (1997) Linkage of a neurophysiological deficit in schizophrenia to a chromosome 15 locus. Proc Natl Acad Sci USA 94:587-592.

Fuchs JL (1989) $\left[{ }^{125} \mathrm{I}\right] \alpha$-bungarotoxin binding marks primary sensory areas of developing rat neocortex. Brain Res 501:223-234.

Geneser-Jensen FA, Blackstad TW (1971) Distribution of acetylcholinesterase in the hippocampal region of the guinea pig. I. Entorhinal area, parasubiculum, and presubiculum. Z Zellforsch 114:460-481.

Gotti C, Hanke W, Moretti M, Longhi R, Balestra B, Briscini L, Clementi F (1995) $\alpha$-Bungarotoxin receptor subtypes. In: Effects of nicotine on biological systems, Pt II (Clarke PBS, Quik M, Adlkofer F, Thurau K, eds), pp 37-44. Boston: Birkhauser Verlag.

Gray R, Rajan AS, Radcliffe KA, Yakehiro M, Dani JA (1996) Hippocampal synaptic transmission enhanced by low concentrations of nicotine. Nature 383:713-716.

Johnson DS, Martinez J, Elgoyhen AB, Heinemann SF, McIntosh JM (1995) $\alpha$-Conotoxin Imi exhibits subtype-specific nicotinic acetylcholine receptor blockade: preferential inhibition of homomeric $\alpha 7$ and $\alpha 9$ receptors. Mol Pharmacol 48:194-199.

Kafka SH, Corbett R (1996) Selective adenosine A2A receptor/dopamine D2 receptor interactions in animal models of schizophrenia. Eur J Pharmacol 295:147-154.
Levin DL (1992) Nicotinic systems and cognitive function. Psychopharmacology 108:417-431.

McGehee DS, Heath MJS, Gelber S, Devay P, Role LW (1995) Nicotine enhancement of fast excitatory synaptic transmission in CNS by presynaptic receptors. Science 269:1692-1696.

McGehee DS, Role LW (1995) Physiological diversity of nicotinic acetylcholine receptors expressed by vertebrate neurons. Annu Rev Physiol 57:521-546.

McGehee DS, Role LW (1996) Memories of nicotine. Nature 383:670-671.

Miner LL, Collins AC (1989) Strain comparison of nicotine-induced seizure sensitivity and nicotinic receptors. Pharmacol Biochem Behav 33:469-475.

Ohno M, Yamamoto T, Watanabe S (1993) Blockade of hippocampal nicotinic receptors impairs working memory but not reference memory in rats. Pharmacol Biochem Behav 45:89-93.

Orr-Urtreger A, Seldin MF, Baldini A, Beaudet AL (1995) Cloning and mapping of the mouse $\alpha 7$-neuronal acetylcholine receptor. Genomics 26:399-402.

Picciotto MR, Zoll M, Lena C, Bessis A, Lallemand Y, LeNovere N, Vincent P, Pich EM, Brulet P, Changeux J-P (1995) Abnormal avoidance learning in mice lacking functional high-affinity nicotine receptor in the brain. Nature 374:65-67.

Pugh PC, Berg DK (1994) Neuronal acetylcholine receptors that bind $\alpha$-bungarotoxin mediate neurite retraction in a calcium-dependent manner. J Neurosci 14:889-896.

Rakhilin SV, Atluri P, Drisdel RC, Ko E, Rangwala F, Salman WN, Green WN (1996) $\alpha 7 / 5 \mathrm{HT}_{3}$ chimeric homomers: similarity to PC12 $\alpha$-bungarotoxin receptors. Neuroscience 22:1521.

Sambrook J, Fritsch EF, Maniatis T (1989) Molecular cloning. A laboratory manual. Cold Spring Harbor, NY: Cold Spring Harbor Laboratory.

Sargent PB (1993) The diversity of neuronal nicotinic acetylcholine receptors. Annu Rev Neurosci 16:403-443.

Schoepfer R, Conroy WG, Whiting P, Gore M, Lindstrom J (1990) Brain $\alpha$-bungarotoxin binding protein cDNAs and mAbs reveal subtypes of this branch of the ligand-gated ion channel gene superfamily. Neuron 5:35-48.

Séguéla P, Wadiche J, Dineley-Miller K, Dani JA, Patrick JW (1993) Molecular cloning, functional properties, and distribution of rat brain $\alpha_{7}$ : a nicotinic cation channel highly permeable to calcium. J Neurosci 13:596-604.

Sloviter RS (1982) A simplified Timm stain procedure compatible with formaldehyde fixation and routine paraffin embedding of rat brain. Brain Res Bull 8:771-774.

Soriano P, Montgomery C, Geske R, Bradley A (1991) Targeted disruption of the c-src proto-oncogene leads to osteopetrosis in mice. Cell 64:693-702.

Steinlein OK, Mulley JC, Propping P, Wallace RH, Phillips HA, Sutherland GR, Scheffer IE, Berkovic SF (1995) A missense mutation in the neuroinal nicotinic acetylcholine receptor $\alpha 4$ subunit is associated with autosomal dominant nocturnal frontal lobe epilepsy. Nat Genet 11:201-203.

Stitzel JA, Robinson SF, Marks MJ, Collins AC (1997) Differences in response to nicotine are determined by genetic factors. Adv Pharmacol Sci 279-284.

Treinin M, Chalfie M (1995) A mutated acetylcholine receptor subunit causes neuronal degeneration in C. elegans. Neuron 14:871-877.

Whiting PJ, Lindstrom JM (1988) Characterization of bovine and human neuronal nicotinic acetylcholine receptors using monoclonal antibodies. J Neurosci 8:3395-3404.

Wonnacott S (1986) $\alpha$-Bungarotoxin binds to low-affinity nicotine binding sites in rat brain. J Neurochem 47:1706-1712.

Woolf NJ (1991) Cholinergic systems in mammalian brain and spinal cord. Prog Neurobiol 37:475-524.

Zarei MM, Dani JA (1995) Structural basis for explaining open-channel blockage of the NMDA receptor. J Neurosci 15:1446-1454.

Zhang Z-W, Coggan JS, Berg DK (1996) Synaptic currents generated by neuronal acetylcholine receptors sensitive to $\alpha$-bungarotoxin. Neuron 17:1231-1240.

Zhang Z, Vijayaraghavan S, Berg D (1994) Neuronal acetylcholine receptors that bind $\alpha$-bungarotoxin with high affinity function as ligandgated ion channels. Neuron 12:167-177.

Zorumski CF, Thio LL, Isenberg KE, Clifford DB (1992) Nicotinic acetylcholine currents in cultured postnatal rat hippocampal neurons. Mol Pharmacol 41:931-936. 